\title{
Organizational Culture Assessment at Ethio-Telecom Using Competing Value Framework
}

\author{
Abadir Abrahim and Shimelis Zewdie
}

\begin{abstract}
The purpose of this study is to assess current dominant and future desired organizational culture at Ethiotelecom Jimma region offices as perceived by employees using competing value framework. The objective is to identify and understand cultural changes needed to manage organizational change Ethio-telecom embarks on effectively. Through a survey research design, a sample of 100 employees who were randomly selected took part in the study. Organizational change assessment instrument (OCAI), standard questionnaire developed by Cameron and Quinn's (2006) used to collect data from respondents. Four types of culture clan, adhocracy, hierarchy, and market assessed from six attributes of culture or dimensions: dominant characteristics, organizational leadership, and management of employees, organizational glue, strategic emphasis, and criteria of success. Standard mean score ( $Z$ score), t-test and analysis of variance employed to address the research questions. The results show that clan culture is the dominant typology at the moment while market oriented culture is found as future desired organizational culture. Moreover, the findings revealed statistically no significant variation among employees in their perception of current dominant culture and choice of future desired culture.
\end{abstract}

Index terms - Competing value framework; culture profile; dominant culture; organizational culture; preferred culture.

\section{INTRODUCTION}

\section{A. Background of the Study}

Organizations often focus on change initiatives such as TQM, downsizing, reengineering, and teamwork in their effort to bring organizational change. However, these change initiatives fall short of expectations' [1] primarily because fundamental organizational change requires not only initiatives but also equally shift in organization's direction, values, and culture. In other words, this is to mean that any initiative, technique, or program of change alone could not be sufficient and change in culture needs to be also considered simultaneously to enhance organizational performance and effectiveness as well as managing change in the organization.

As [2] stated organizational culture reflects employees' shared values, beliefs, symbols, ceremonials, and traditions in a company and constitutes one of the most important key success factors in any organization trying to achieve excellence in its business. Organizational culture is not a static entity, it changes in time and introduce changes to the

Published on December 31, 2020.

Abadir Abrahim, Jimma Teacher's College, Jimma, Ethiopia.

(e-mail: robaunyo@gmail.com)

Shimelis Zewdie, Department of Management, Jimma University, Jimma, Ethiopia.

(e-mail: shimmzz@yahoo.com) organizations with itself. [3] explained that organizational culture as the pattern of basic assumptions that a group has invented or discovered in learning to cope with its problems of external adaptation and internal integration, and that have worked well enough to be considered valid and, therefore, to be taught to new members as the correct way to perceive, think, and feel in relation to those problems. He further indicated that culture is a dynamic process, resulting from the interaction among others and promoted by leadership behaviors. It encompasses a set of structures, routines, rule,s and norms that guide and constrain behaviour.

Organizational culture could be a source of sustained competitive advantage [4]. Various empirical investigation indicated the role of organizational culture in improving employee retention [5], knowledge management [6], organization effectiveness [7] innovation [8], and performance [9]. To achieve these beneficial attributes in terms of sustained competitive advantages, organizational culture must be valuable, rare, and difficult to imitate [10]. Moreover, organizational culture can serve as a source of distinctions among organizations and can transmit a perception of identity for organization members, can promote the commitment, strengthen stability and consistency of the organization and can help to manage the behaviours of the members of the organization by shaping their shared values and beliefs [11], [12].

Therefore, any empirical investigation of organizational culture has apparently paramount importance especially for organization on the road to adopt change like EthioTelecom. Following the government's decision to privatize telecom industry, international firms are joining the market and Ethio-telecom will face competition as a result. Ethiopian companies are often criticized for lacking favourable work culture which could rival foreign competitors. To adapt to the changing environment and cope up with stiff competition Ethio-telecom needs to adopt change. This study would be significant as it identifies current dominant organizational culture at the organization and also indicates desired future organizational work culture needed to manage organizational change Ethio-telecom is embarking on effectively.

\section{B. Purpose Statement}

Organizations tend to develop a dominant organizational culture over time as they adapt and respond to challenges and changes in the environment [13]. Structural changes; increasing turbulence, complexity, and unpredictability of the external environments in which organizations operate have escalated importance of culture as well as managing cultural change. Ethio-telecom is about to introduce structural change to the company by opening up its market 
and ending its long hold on monopoly. Soon it will find itself in strong competition. Among other thing this organizational change requires effective management of culture because organizational culture creates both stability and adaptability for organizations when competition, change, and pressure intensify for organizations [14].

Clarifying core competence and strategic intent are prerequisites to organizational adaptability, and both are grounded squarely in the organization's unique culture. Therefore, organizational culture assessment at Ethiotelecom is timely and important because of the need to change and maintain stability in the face of increasingly challenge. The purpose of this proposed study is therefore to assess the current dominant work culture and future preferred culture at Ethio-telecom Jimma district offices. The objective is to bring more understanding about the current dominant culture and cultural changes needed to manage organizational change effectively by enhancing stability and ability to adapt to changing environment.

Competing value framework (CVF), a model of cultural change proposed by Cameron and Quinn in 2011 used for the assessment. This model introduces the element of cultural evolution and focus on the values held dear by the organization: flexibility, stability, differentiation, or integration. The model has four components or types of culture: adhocracy, clan, hierarchy, and market. The model also describes these typologies of culture based on six dimensions: dominant characteristics, organizational leaders, management of employees, organizational glue, strategic emphases, and criteria of success. According to [15] CVF model is intended to promote successful management, improvement of organizational efficiency and creation of value for the organization. In addition, the model

is important for this study as it focuses on the change required in an organization.

\section{Basic Research Questions}

1. What is the dominant organizational culture existing now at Ethiotelecom Jimma offices?

2. What cultural changes preferred in the future to manage organizational change effectively at Ethiotelecom?

3. Do employees vary in their perception of existing or preferred organizational culture based on their demographic characteristics (age, sex and functional departments)?

\section{Objective of the Study}

\section{General objective}

The main purpose of this study is to assess the current dominant and desired future organizational culture at EthioTelecom Company Jimma District Offices to identify cultural changes needed to manage change effectively.

\section{Specific objectives}

- Explore current dominant organizational culture at Ethio-telecom Jimma district offices.

- Identify future preferred cultural change required to manage organizational change effectively.

- Examine if there is significant difference between employees in their perception of current culture and their choice of future desired organizational culture based on age, sex, and functional departments.

\section{E. Scope of the Study}

Geographically this study focused on Ethio-telecom offices based in Jimma town. Since culture is a shared belief system, location rarely affects the nature and type of work culture of a given organization in a given period of time. Hence the researcher believes that Ethio-telecom offices in Jimma could represent other offices in the country. Cameron and Quinn model of cultural change model adopted for the study. The model assesses four typologies of culture based on six dimensions, dominant characteristics, organizational leaders, management of employees, organizational glue, strategic emphases, and criteria of success. Using this conceptual framework, the study developed cultural profile.

\section{F. Significance of the Study}

his study intended to serve a number of purposes. First and foremost, it enriches our understanding of the work culture as it exists today in Ethio-telecom Company with reference to Jimma branch main office. The study is also important in bringing the issue of organizational culture which has been less emphasized in research among academic circle to encourage similar more research in the area. Moreover, organizations often underestimate the necessity or importance of simultaneous culture change whenever they introduce change to their organization. Thus, this study could also useful and informative for organization since Ethio-telecom is going under structural changes.

\section{LITERATURE REVIEW}

\section{A. Theoretical Review}

\section{Organizational culture}

It is often difficult to describe or define culture directly in simple terms. Hence, many attempted to define it indirectly by describing the components of culture or what culture constitutes. The same goes for organizational culture. According to various definitions given by different scholars organizational culture commonly refers to a system of values, beliefs and behaviour shared among employees [1], [3], [16]. It is pattern of basic assumptions invented by group or discovered in learning to cope with its problems of external adaptation and internal integration that have worked well enough to be considered valid and, therefore, to be taught to new members as the correct way to perceive, think, and feel in relation to those problems. Culture is a dynamic process, resulting from the interaction among others and promoted by leadership behaviours. It encompasses "a set of structures, routines, rules and norms that guide and constrain behaviour [3].

Corporate culture can also be defined as the taken-for granted views on how the organization sees itself and its environment. It includes the organizational structure, hierarchy, management practices and the work style [16]. It also influences the set of personal and professional goals of people and the ways to manage them by allocating beneficial resources in order to achieve and perform in different tasks. Usually, a mix of explicit and implicit rules and behaviours, a corporate culture can be enunciated in both written and unwritten way through norms and values, which are important for an organization. [17] stated that 
corporate culture in general is determined by three: the general relationship between employee and organization; the authority system which defines managers and subordinates by a vertical or hierarchical system, and the employees' opinions about their place in the organization's future, purpose, and goals. Favourable strong corporate culture form cohesion and improve performances by committing members of the organization in a stronger way. In other words, a high level of commitment and performance is possible if employees adopt and share values and beliefs that the corporate culture stands for.

\section{Models of organizational culture}

Various cultural models applied to different studies as they deemed fit to given situation over the years. Four known models summarized by [15] as illustrated below in the table.

TABLE I: ORGANIZATIONAL CULTURE MODELS

\begin{tabular}{|c|c|c|c|c|}
\hline & Harrison & $\begin{array}{l}\text { Deal and } \\
\text { Kennedy }\end{array}$ & Schneider & $\begin{array}{c}\text { Cameron and } \\
\text { Quinn }\end{array}$ \\
\hline \multirow{4}{*}{$\begin{array}{l}\text { Name of } \\
\text { Quadrants }\end{array}$} & Achievement & $\begin{array}{c}\text { Bet your } \\
\text { company } \\
\text { Work }\end{array}$ & Cultivation & Adhocracy \\
\hline & Person & $\begin{array}{c}\text { hard /play } \\
\text { hard }\end{array}$ & Collaboration & Clan \\
\hline & Power & Process & Control & Hierarchy \\
\hline & Role & $\begin{array}{l}\text { Though- } \\
\text { guy }\end{array}$ & Competence & Market \\
\hline $\begin{array}{l}\text { Primary } \\
\text { focus }\end{array}$ & $\begin{array}{c}\text { Process } \\
\text { conduction } \\
\text { and decision } \\
\text { making }\end{array}$ & $\begin{array}{l}\text { Kinds of } \\
\text { decisions }\end{array}$ & $\begin{array}{l}\text { General way } \\
\text { of thinking in } \\
\text { the decision } \\
\text { making } \\
\text { process }\end{array}$ & $\begin{array}{l}\text { Values held } \\
\text { dear by } \\
\text { organization }\end{array}$ \\
\hline
\end{tabular}

The four models shown above describe different aspects of culture. Harrison focuses on how processes are conducted, and decisions are made within a culture. Deal and Kennedy focus on the kinds of decisions that have to be made. Schneider focuses more on the general way of thinking in the decision making process. Cameron and Quinn introduce the element of cultural evolution and focus on the values held dear by the organization: flexibility, stability, differentiation, or integration.

\section{B. Empirical Review}

Sinha, Singh, Gupta and Dutt [18] examined the dominant work culture prevalent in the two private sector manufacturing organizations and its impact on employees' performance and motivation level in Nigeria. Autocratic culture, bureaucratic culture, technocratic culture, and entrepreneurial culture were investigated as components of culture. These components were statically correlated to performance and motivation. The findings showed that technocratic culture was a strong predictor of motivation while the entrepreneurial culture strongly predicts performance [18]. Similar studies made by [21] revealed that organizational culture has a direct impact on employee motivation and indirect impact on organizational performance. It was observed that a strong culture of rewarding and acknowledging employees' effort, leads to increased motivation and performance.

Parthasarathy and Ramalingam [20] explored the relationship between organizational culture and employee motivation. In their study, they investigated if the impact of organizational culture does differ significantly across the organization as perceived by the employees working in the organization. The result suggested that there is significant difference in the mean of organizational culture factor across the organizational outcome as perceived by the employees [20]. Enhanced employee motivation could be resulted from appropriate organizational culture. Yusof et al [22] Cheeran et al. [19] came up with similar result which indicates the role supportive culture for employee motivation improvement.

Meta-analysis made based on 84 empirical studies by Hartnell, Yi Ou and Kinicki [23] using Quinn and Rohrbaugh's 1983 competing values framework (CVF) examined relationship between cultural typologies and major indices of organizational effectiveness. Results indicate that clan, adhocracy, and market cultures are differentially and positively associated with the effectiveness criteria. Clan cultures were most strongly associated with positive employee attitudes and product and service quality, whereas market cultures are most strongly related with innovation and financial effectiveness criteria. Finally, they suggested the need by leaders to consider the fit between strategic initiatives and organizational culture when determining how to embed a culture that produces competitive advantage.

Kokt and Merwe [24] studied the proliferation of crime in the South African private security industry using competing value framework. The findings provided an insight for managers how their cultural orientation affects their functioning and ultimately their competitive advantage. AlHarbi and Abedelrahim [25] studied organizational culture using competing value framework at Tabuk University in Saudi Arabia. Data collected from a sample of 322 participants consisting of academic staff and employees of Tabuk University. The findings revealed clan culture as a dominant one. In addition, the results also indicate statistically significant differences in culture strength based on the nature of demographic characteristics.

Silva et al., [26] investigated the relationships between the actual and the desired culture in the Brazilian health organizations' culture. The authors used Competing Values Framework as guiding principle. The data collected from Belo Horizonte and two other cities using OCAL scale. The study found the dominance of a hierarchical culture with an internal focus and dominant control as current culture in the organizations. The study also similarly found a hierarchical culture with an internal focus and dominance for Control over Flexibility as future desired cultural typology.

As opposed to the other empirical studies Santoriello [27] research focused on development of a technique to extend the application of the CVF to identify the core values unique to a given organization. Through grounded theory method he developed and empirically tested the CVF-based Core Values Identification Technique (CCVI) and at three companies. This technique aims to guide organizational change effort.

Competing value framework as a conceptual guiding principle used in various empirical studies in different organizations or industries as shown in the studies above. The objectives range from leaning the existing cultural orientation to diagnosing or changing cultural orientation to 
help organization to adapt to changing business environment and gaining competitive advantage. In this respect, in this study CVF was used to identify current dominant culture and future desired culture to help the company Ethiotelecom manage organizational change it embarks on successfully.

\section{Conceptual Framework}

For this study the Cameron and Quinn model illustrated below chosen to guide the process of this study as a framework. This model, which is also known as focus or competing value model, is a general model intended to promote successful management, improvement of organizational efficiency and creation of value for the organization [15]. In addition, the model is important for this study as it focuses on the change required in an organization to improve work performance by enabling the assessment of existing and preferred culture. Therefore, it is important for meeting the objectives of this proposed study and helps understand the prevalent culture in the Ethiopian power utility and cultural changes preferred to navigate organizational changes successfully.

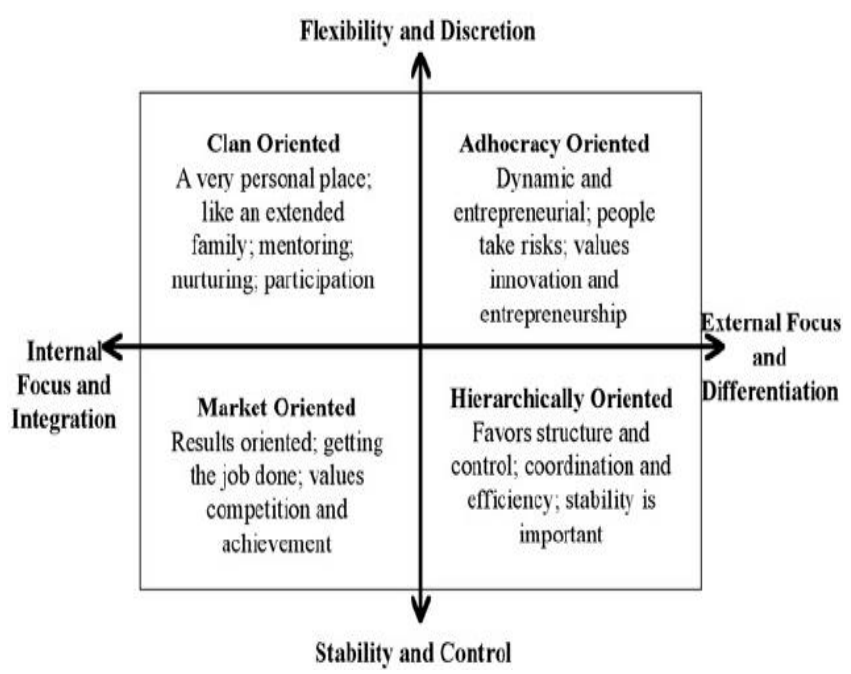

Fig. 1. Competing value framework by Cameron \& Quinn [28].

The Competing Values Framework (CVF) provides a means of quantifying culture and has a strong and wellestablished empirical basis for cultural diagnosis [29]. The CVF serves as a sense-making device to help leaders, managers, and employees understand and navigate the inherent cultural tension, or "competing values", within their organization. The framework is based on the notion that all human activity has an underlying structure. Organizations, by definition, exhibit patterns and predictability in relationships and the CVF serves to identify dimensions to these relationships.

Two primary dimensions used in the CVF: flexibility vs. stability and efficient internal process vs. competitive external positioning [30]. Orienting these two dimensions on horizontal and vertical axes reveals a two-by-two matrix with four quadrants, known in the CVF as clan, adhocracy, hierarchy, and market which situated in different quadrant as illustrated above. Each quadrant represents a distinct cluster of criteria relating to the way people process information, learn about their environment, organize, and lead others, create value for customers, and how they see what is right, good, or appropriate.

The model along with the Organizational Cultural Assessment Instrument (OCAI) developed by [1] can help organizations identify their current and preferred culture. Using a simple survey, participants identify their perceptions of both existing culture and their desired future culture. Organizations can then utilize these results to assess both the current cultural state and also to identify gaps between current and desired futures.

\section{METHODS AND MATERIALS}

\section{A. Research Design}

This study adopted survey research design. It is a procedure in quantitative research in which investigators administer a survey to a sample or to the entire population of people to describe the attitudes, opinions, behaviours, or characteristics of the population [31]. It mainly describes trends in the data and focus more on learning about a population and practices exist. Hence it was appropriate and important to achieve objective of the study which is mainly to determine the current dominant and future desired organizational culture at Ethio-telecom through assessment of employees' perception and attitude.

\section{B. Population, Sample, and Sampling Technique}

This study targeted employees of Ethio-telecom currently working at Jimma district offices. In these offices roughly there are about 250 workers working in six different main divisions: human resource, facility, power, marketing, finance, and sales. There may be subcultural difference between major divisions [13]. Thus, these major divisions should be used as strata. Stratified sampling techniques will be employed to draw proportionate sample which is representative of each division after study sample determined from the sample frame through Yamane's 1967 formula. With $50 \%$ of population proportion, at $95 \%$ degree confidence level and 5 percent margin of errors the actual sample size or valid sample size was computed as follows.

$$
n=\frac{N}{1+N\left(e^{2}\right)}
$$

where

$n$ is the required sample size.

$N$ is the total population.

$e$ is the margin of error required.

$$
n=\frac{250}{1+250\left(.05^{2}\right)}=250 / 1.625=154
$$

Therefore, the required minimum sample size is 154 individuals but since the population size was small it is advisable to adjust further the minimum sample size as illustrated below.

$$
n^{\prime}=\frac{n}{1+\frac{n}{N}}
$$


where

$\mathrm{n}^{\prime}$ is the adjusted minimum sample size.

$\mathrm{n}$ is the minimum sample size (as calculated above).

$\mathrm{N}$ is the total population.

$$
\begin{gathered}
\mathrm{n}^{\prime}=154 / 1.616=95.29 \\
\mathrm{n}^{\prime}=95
\end{gathered}
$$

Final sample size $=105(95+10 \%$ response rate error $)$.

\section{Data Collection Techniques and Measurements}

Standard survey questionnaire, better known as organizational culture assessment instrument (OCAI) developed by [1] employed for data collection. OCAI is based on the competing values framework model consisting of four typologies of cultures: clan, adhocracy, hierarchy, and market. This instrument aims to identify dominant organizational culture exist now and help to identify the culture that the organization's members think should be developed to match the future demands of their industry. Six key dimensions of organizational culture: dominant characteristics, leadership style, employee development, organizational glue, strategic emphasis, and criteria of success. Each dimension consists of four items, "A", "B", "C" and "D" which represent respectively clan, adhocracy, hierarchy, and market typology of culture (see appendix 1).

The participants filled the same question twice under different heading i.e., 'Part one' and 'part two'. Part one refers to the current organizational culture as it exists today in the organization. Part two refers to the preference of organizational culture employees interested to have in the future. The original OCAI uses ipsative rating scale which divides individual response among alternatives. However, in this study five point Likert scale (ranging from 1 strongly disagree to 5 strongly agree) used to produce independent responses.

The OCAI uniquely identify the organization's cultural strength, congruence, and type. To identify dominant existing culture and future cultural preferences standard mean score (Z-Score value) calculated from raw means computed for all four typologies of culture (A, B, C and D) under each dimension. Based on this the overall cultural profile of an organization plotted in diagram to tell what type of culture the organization possesses and what cultural change desired in the future. This can help detect the extent to which one or more cultures are strong (or dominant) in the organization. This instrument is the most reliable and widely used tools in organizational culture research. For example, a coefficient of .74 for the clan culture, .79 for the adhocracy culture, .73 for the hierarchy culture, and .71 for the market culture were reported in various previous studies [1].

Similarly, the reliability of these items was checked in pilot test in this study and the following alpha coefficients obtained for all types of culture as illustrated below in the table.
TABLE II: RELIABILITY TEST

\begin{tabular}{lccc}
\hline & Cultural Typology & No. items & $\begin{array}{c}\text { Cronbach's } \\
\text { alpha }\end{array}$ \\
\hline \multirow{3}{*}{ Organizational } & Clan & 6 & 0.680 \\
culture & Adhocracy & 6 & 0.558 \\
& Hierarchy & 6 & 0.769 \\
& Market & 6 & 0.692 \\
\hline
\end{tabular}

The table illustrates corresponding Cronbach's alpha coefficient value of .680 for clan, .558 for adhocracy, .769 for hierarchy and .692 for market oriented culture respectively. An alpha coefficient above 0.65 or 0.7 is considered desirable in terms of internal consistency [28]. Hence the alpha results found are acceptable and in line with previous test findings and good for the validity of this study.

Finally, survey questions were distributed in person to a total of 105 employees of Ethio-telecom Jimma offices. Among these the responses of 100 individuals who returned the questionnaire were used. The other remaining 5 questionnaires were rejected due to different reasons. Based on this information we can see that the response rate of the study which was $95 \%$ is desirable.

\section{Method of Data Analysis}

The data obtained was analyzed using procedure that passed through three steps. The first step was preliminary analysis where data was inspected and prepared for further analysis. Second the data descriptively analyzed to identify general trends: develop demographic profile of the sample; calculate and present a table of descriptive statistics (mean, percent, and frequency) on the instrument, and provide answers to descriptive questions that aim to explore the existing and preferred organizational culture in the organization under investigation. Finally, the data analyzed through inferential statistical tool - ANOVA or analysis of variance to answer or examine the existence of significance difference between employees involved in the study based on their age, sex, and functional departments.

\section{E. Ethical Issues}

I think is crucial to address ethical issues of concern to all parties involved in the study. Hence in this study, first organization notified through letter regarding the objective of the study to seek indirect consent from the participants. Confidentiality of the responses of the participants ensured at all levels during the course of the study.

\section{ANALYSIS, RESULTS AND DISCUSSION}

This section deals with analysis of the data and interpretation of the results of the study. It developed into four main sub sections: preliminary analysis, descriptive statistical analysis, inferential statistical analysis, and discussion of the results.

\section{A. Preliminary Analysis}

This part mainly involved examining, preparing, and summarizing data for analyses. Before analysis the collected data was coded and inspected visually as well as via plot and graphs to check missing values, identifying outlier and out of rage values. Finally, the cleaned data entered data management software and analyzed descriptively and inferentially to address research questions. 
B. Demographic Profiles

TABLE III: GENDER OF THE PARTICIPANT

\begin{tabular}{llcccc}
\hline \multicolumn{7}{c}{ Sex } \\
\hline & Frequency & Percent & Valid Percent & $\begin{array}{c}\text { Cumulative } \\
\text { Percent }\end{array}$ \\
\hline \multirow{2}{*}{ Valid } & Male & 64 & 64.0 & 64.0 & 64.0 \\
& Female & 36 & 36.0 & 36.0 & 100.0 \\
& Total & 100 & 100.0 & 100.0 & \\
\hline \multicolumn{7}{c}{ Age and experience } \\
\hline \multicolumn{7}{c}{ Minimum } & Maximum & Mean & Std. \\
& $\mathrm{N}$ & \multicolumn{7}{c}{ Deviation } \\
\hline Age & 100 & 20 & 55 & 32.30 & 7.773 \\
Work experience & 100 & 2 & 34 & 8.95 & 7.036 \\
Valid N (listwise) & 100 & & & & \\
\hline
\end{tabular}

Sex wise the majority of the employees were males. They roughly account about $64 \%$ which was almost two-third of the total population. As illustrated above females were fewer in number than their male counterparts and the figures show they account about $36 \%$. In terms of age the minimum age was 20 while the maximum was 55 and average age was 32.3. Work experience at the organization ranges from minimum 2 years to the maximum 34 years. Roughly about $90 \%$ of the workers had work experience of 15 years and below. From the total of 12 departments which are currently under operation in Ethiotelecom 10 were represented in the study population. The major ones along with number of participants were key account 10, audit and finance 16, customer service 32, logistics 20 and human resource and maintenance 17 .

\section{Descriptive Statistical Analysis}

The Organizational Culture Assessment Instrument assesses six key dimensions of organizational culture (dominant characteristics, organizational leadership, and management of employee, organizational glue, strategic management, and criteria of success) under four major typologies of culture: clan, adhocracy, hierarchy, and market. Hence the four typologies represent main variables of analysis. The purpose here is to identify current dominant culture and future desired culture based on the opinion of employees of the organization. The respondents rated the instrument twice under 'now' and 'preferred' parts which respectively indicate current dominant culture and desired future culture in the organization. Therefore, average values computed for current dominant culture as well as future desired culture as illustrated below in the Table V and VI.

\section{1) Current dominant culture}

To identify current dominant culture first average mean score was calculated for all four variables of type of culture. To interpreted the scores more meaningfully average raw mean scores converted into standard mean by computing $\mathrm{Z}$ score values for each culture. Hence based on the standard mean value scores as demonstrated in the table below 'clan' is found the current dominant organizational culture (Mean= 4.07 and $\mathrm{SD}=1.5$ ) as perceived by the employees or the workers of the company.

Correspondingly, hierarchy and market are the least perceived or visible organizational culture at this moment in the organization. The lowest score point for these typologies indicated that they are weak culture as perceived by the workers.
TABLE IV: AVERAGE SCORE FOR CURRENT CULTURE

\begin{tabular}{cccccccc}
\hline \multicolumn{7}{c}{ Descriptive Statistics } \\
\hline Clan & $\mathrm{N}$ & Min & Max & Mean & SD & Z Score & St.Mean \\
\cline { 2 - 8 } Adhocracy & 100 & 1 & 5 & 2.91 & 1.62 & 1.1684 & 4.071 \\
Hierarchy & 100 & 1 & 5 & 2.46 & 1.29 & 0.7251 & 3.185 \\
Market & 100 & 1 & 5 & 2.36 & 1.30 & 0.6301 & 2.995 \\
\hline Valid N & 100 & 5 & 2.33 & 1.54 & 0.5967 & 2.928 \\
\hline
\end{tabular}

\section{2) Preferred future culture}

As opposed to clan culture which is found dominant at the moment in the organization, market culture (Mean $=4.15$ and $\mathrm{SD}=1.1$ ) is found the desired future organizational culture aspired by employees in the years to come. For the future employees want the market culture to dominate their organization overwhelmingly. The least favored organizational culture in the future is clan (Mean=1.7 and $\mathrm{SD}=1)$ and adhocracy (Mean=1.9 and $\mathrm{SD}=0.91)$.

TABLE V: AVERAGE SCORE FOR DESIRED Future CULTURE

\begin{tabular}{cccccccc}
\hline & \multicolumn{7}{c}{ Descriptive Statistics } \\
\cline { 2 - 8 } Clan & $\mathrm{N}$ & Min & Max & Mean & Std. D & Z valu & St.Mean \\
Adhocracy & 100 & 1 & 5 & 2.03 & 1.06 & -0.32 & 1.71 \\
Hierarchy & 100 & 1 & 5 & 2.1 & 0.91 & -0.22 & 1.92 \\
Market & 99 & 1 & 5 & 2.28 & 0.98 & -0.07 & 2.21 \\
Valid N & 99 & 5 & 3.25 & 1.18 & 0.89 & 4.15 \\
\hline
\end{tabular}

\section{3) Organizational culture profile}

The following figure shows the cultural profile of Ethiotelecom company Jimma zone which is drawn based on the summary of OCAI score points for four typologies of culture illustrated below in the table.

TABLE VI: SUMmARY AVERAGE MEAN SCORES

\begin{tabular}{ccc}
\hline & \multicolumn{2}{c}{ Summary } \\
\hline & Now (current culture) & Preferred (desired culture) \\
\cline { 2 - 3 } Clan & 4 & 1.70 \\
Adhocracy & 3.2 & 1.92 \\
Hierarchy & 2.9 & 2.20 \\
Market & 2.9 & 4.15 \\
\hline
\end{tabular}

The cultural profile figure below portrays clan as dominant current culture and market as desired future culture. By selecting clan as a dominant existing culture, the employees indicated that the organization is much like an extended family and a very pleasant place to work. At the same time people share a lot of personal information.

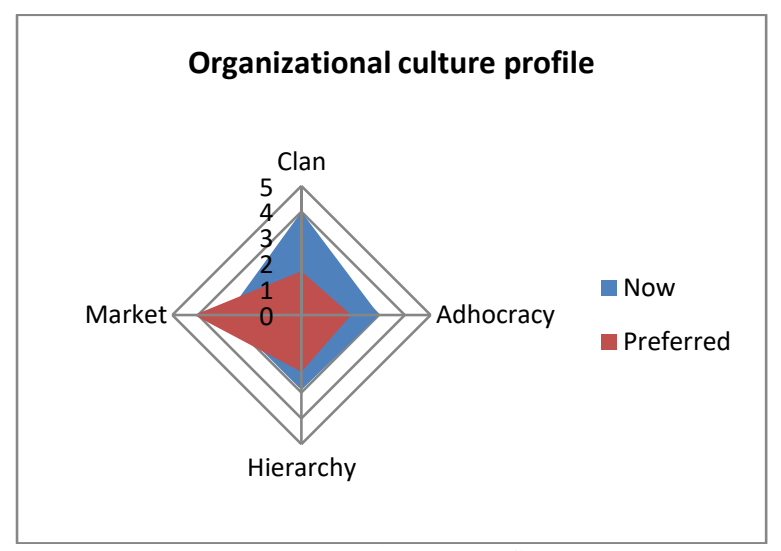

Fig. 2. Organizational culture profile.

The leaders or heads of the organization are seen as mentor and perhaps even parent figures. According to 
Cameron and Quinn [1], organization having clan as strong culture is held together by loyalty or tradition and commitment is high as well. The organization emphasizes the long-term benefit of human resources development and attaches great importance to cohesion and morale. Success is defined in terms of sensitivity to customers and concern for people. The organization places a premium on teamwork, participation, and consensus.

An organization that prefers a market culture for future business endeavours is a result-oriented organization that mainly concerned in getting the job done. In such organization people are competitive and goal oriented. The leaders are hard drivers, producers, and competitors. They are tough and demanding. The glue that holds the organization together is an emphasis on winning. Reputation and success are common concerns. The long-term focus is on competitive actions and achievement of measurable goals and targets. Success is defined in terms of market share and penetration. Competitive pricing and market leadership are important. The organizational style is hard-driving competitiveness [1].

The organizational cultural profile along with its subsequent analysis effectively answered the first two basic research questions which enquired the current dominant organizational culture at the organization and future preferred cultural typology.

\section{Inferential Statistical Analysis}

Organizational culture encompasses the taken-for-granted values, underlying assumptions, expectations, collective memories which often obscured [14]. To bring the needed cultural changes it is important to ascertain if employees at Ethio-telecom Jimma offices share the same underlying assumptions, expectation, and common collective memories regarding what they are now and where they want to be in the future. T-tests and analysis of variance (one-way ANOVA) was employed to see if mean scores of employees' responses differ in the way they perceive the current existing culture and cultural changes needed in the future to enhance work performance and effectiveness. Sex age, tenure or lengths of work experience and employees work department were used as important grouping variables.

\section{1) T-Tests}

Based on sex as a grouping variable there was not statistically significant difference among employees in their response to the typologies of existing organizational culture i.e., clan between male $(\mathrm{M}=26.60, \mathrm{SD}=8.908)$ and female $[(\mathrm{M}=30.05, \mathrm{SD}=9.233, \mathrm{t}(84)=-1.711, \mathrm{p}=.091)]$. In the same way in terms of future preferred cultural choice(market) there was no significant difference between male $(\mathrm{M}=27,74 \mathrm{SD}=9.354)$ and female $[(\mathrm{M}=27.18, \mathrm{SD}=$ 9.662, $\mathrm{t}(92)=0.273, \mathrm{p}=.785)]$. All values are statistically significant at $95 \%$ confidence interval or degrees of freedom or at $\mathrm{p}<0.05$. In other words, it means that employees share and hold similar values, assumptions, and expectation regarding their workplace.

TABLE VII: T-TEST (SEX)

Independent Samples Test

\begin{tabular}{|c|c|c|c|c|c|c|c|c|c|c|}
\hline \multicolumn{11}{|c|}{ 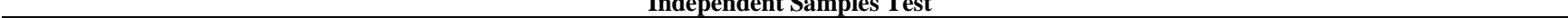 } \\
\hline & & \multicolumn{2}{|c|}{ Levene's Test } & \multicolumn{7}{|c|}{ t-test for Equality of Means } \\
\hline & & \multirow{2}{*}{$\mathrm{F}$} & \multirow{2}{*}{ Sig. } & \multirow{2}{*}{$\mathrm{t}$} & \multirow{2}{*}{ df } & \multirow{2}{*}{ Sig. } & \multirow{2}{*}{ MD } & \multirow{2}{*}{ SE } & \multicolumn{2}{|c|}{$95 \% \mathrm{CI}$} \\
\hline & & & & & & & & & $\mathrm{L}$ & $\mathrm{U}$ \\
\hline \multirow{2}{*}{ Clan } & Eq.V. A & .171 & .680 & -1.71 & 84 & .091 & -3.44 & 2.014 & -7.45 & .559 \\
\hline & Eq.V not assumed & & & -1.69 & 63.35 & .095 & -3.44 & 2.033 & -7.51 & .615 \\
\hline \multirow{2}{*}{ Market } & Eq.V assumed & .287 & .593 & .273 & 92 & .785 & .555 & 2.032 & -3.48 & 4.590 \\
\hline & Eq.V. not assumed & & & .271 & 66.82 & .788 & .555 & 2.050 & -3.53 & 4.647 \\
\hline
\end{tabular}

2) Analysis or variance

Similarly, one-way analysis of variance between groups conducted to explore differences in the existing and future preferences of cultural changes need in the organization. The subjects were divided into four groups according to their age (Group 1: 20-30; Group 2: 31 - 40; Group 3: 4150; Group 4: above 50). As the table below illustrates there was no statistically significant difference at the $\mathrm{p}<.05$ level in clan $[\mathrm{F}(3,82)=.761, \mathrm{p}=.519]$ and $\operatorname{market}[\mathrm{F}(3,90)=1.929$, $\mathrm{p}=.131]$ scores for all group ages. Post-hoc comparisons using the Tukey HSD test indicated that the mean score for all groups were not significantly different from one another.

TABLE VIII: ANALYSIS OF VARIANCE BASED ON AGE

\begin{tabular}{clccccc}
\multicolumn{7}{c}{ ANOVA } \\
\hline \multirow{6}{*}{ Clan } & Sum of Sq & Df & $\begin{array}{c}\text { Mean } \\
\text { Square }\end{array}$ & F & Sig. \\
& $\begin{array}{l}\text { Between } \\
\text { Groups }\end{array}$ & 192.068 & 3 & 64.023 & .761 & .519 \\
& $\begin{array}{l}\text { Within } \\
\text { Groups } \\
\text { Total }\end{array}$ & 6895.012 & 82 & 84.086 & & \\
& Between \\
Market & 7087.080 & 85 & & & \\
Groups & 498.447 & 3 & 166.149 & 1.929 & .131 \\
& Within & 7751.435 & 90 & 86.127 & & \\
& Groups & & & & & \\
\hline
\end{tabular}

However, based on tenure or length of work experience it seems there was statistically significant difference between the groups (Group 1: less than 5; Group 2: 6-10; Group 3:11-15; Group 4: 16-25; Group 5: above 25) in their perception of existing culture $[\mathrm{F}(4,81)=2.560, \mathrm{p}=.045]$ and future preferred culture $[\mathrm{F}(4,89)=.2 .668, \mathrm{p}=.037]$. Despite reaching statistical significance, the actual difference in mean scores between the groups was quite small. The effect size, calculated using eta squared, was 0.11 for clan and 0.107 for market which are classified as small according to Cohen's classification [32]. Post-hoc comparisons using the Tukey HSD test indicated that the mean score for all group was not significantly different from each other.

Alike the other demographic variables groups were not statistically significantly different from one another in terms of their perception of existing culture $[\mathrm{F}(4,81)=2.560$, $\mathrm{p}=.045]$ and future cultural preference $[\mathrm{F}(4,81)=2.560$, $\mathrm{p}=.045$ ] as can be observed below based on their work department. 
TABLE IX: ANALYSIS OF VARIANCE BASED ON WORK TENURE

\begin{tabular}{|c|c|c|c|c|c|c|}
\hline \multicolumn{7}{|c|}{ ANOVA } \\
\hline & & $\begin{array}{l}\text { Sum of } \\
\text { Squares }\end{array}$ & $\mathrm{df}$ & $\begin{array}{c}\text { Mean } \\
\text { Square }\end{array}$ & $\mathrm{F}$ & Sig. \\
\hline \multirow{3}{*}{ Clan } & $\begin{array}{l}\text { Between } \\
\text { Groups }\end{array}$ & 795.268 & 4 & 198.817 & 2.560 & .045 \\
\hline & $\begin{array}{l}\text { Within } \\
\text { Grouns }\end{array}$ & 6291.812 & 81 & 77.677 & & \\
\hline & Total & 7087.080 & 85 & & & \\
\hline \multirow{3}{*}{ Market } & $\begin{array}{l}\text { Between } \\
\text { Groups }\end{array}$ & 883.208 & 4 & 220.802 & 2.668 & .037 \\
\hline & $\begin{array}{l}\text { Within } \\
\text { Groups }\end{array}$ & 7366.673 & 89 & 82.772 & & \\
\hline & Total & 8249.882 & 93 & & & \\
\hline
\end{tabular}

TABLE X: ANOVA BASED ON WORK DEPARTMENT

\begin{tabular}{|c|c|c|c|c|c|c|}
\hline \multicolumn{7}{|c|}{ ANOVA } \\
\hline & & Sum of $\mathrm{Sq}$ & df & Mean Sq & $\mathrm{F}$ & Sig. \\
\hline \multirow{3}{*}{ Clan } & $\begin{array}{l}\text { Between } \\
\text { Groups }\end{array}$ & 868.626 & 9 & 96.514 & 1.180 & .320 \\
\hline & $\begin{array}{l}\text { Within } \\
\text { Groups }\end{array}$ & 6218.454 & 76 & 81.822 & & \\
\hline & Total & 7087.080 & 85 & & & \\
\hline \multirow{3}{*}{ Market } & $\begin{array}{l}\text { Between } \\
\text { Groups }\end{array}$ & 668.261 & 9 & 74.251 & .823 & .597 \\
\hline & $\begin{array}{l}\text { Within } \\
\text { Groups }\end{array}$ & 7581.621 & 84 & 90.257 & & \\
\hline & Total & 8249.882 & 93 & & & \\
\hline
\end{tabular}

Post-hoc comparisons using the Tukey HSD test indicated that the mean score for all groups was not different from another. The above analysis answered the third research question which probes if significant difference exists among employees based on their demographic characteristics: sex, age, work tenure and department. Generally, employees were not significantly different in their perception of current culture and choice of desired future culture for the organization.

\section{E. Discussion of the results}

This study explored the existing and future desired organizational culture at Ethio-telecom Jimma region offices using competing value framework model. This model has been ideal in identifying types of organizational culture and diagnosing cultural change in public companies [14], [2], [33]. The study addressed three main objectives: identifying current dominant organizational culture Ethio-telecom Jimma branch offices; identifying desired or preferred organizational culture those employees want to see in the future at their offices and examine variation among employee's perception in their reflection current dominant culture and choice of desired future culture. To this end this section discussed the results of the study in light of this research objectives vis-à-vis against previous empirical findings as well as model of the study.

Clan typology was relatively found the dominant strong culture in the organization at the moment with the highest average response scores. Hierarchy culture perceived as weak culture. As per the framework these result means at the moment loyalty and commitment is high in the organization. The organization emphasizes the long-term benefit of human resources development and attaches great importance to cohesion and morale. There is concern for people and teamwork, participation, and consensus are important values. Internal focus and flexibility prevail now in the organization. These encourage broad participation by employees, give emphasis to teamwork and empowerment, and make human resource development a priority [33].

Nevertheless, employees want the market culture to dominate their organization in the future. Employees want their organization more result-oriented and concerned mainly in getting the job done. People are also need to be competitive and goal oriented. They want to see or emphasize on winning rather than loyalty as glue to holds their organization together which is currently the case. Reputation and success are common concerns than people and customers. The long-term focus is on competitive actions and achievement of measurable goals and targets. Competitiveness and market share are considered important values. Organizations within which external focus and control prevail (usually labelled market or rational cultures) are characterized by clarity of tasks and goals. Such organizations address attention to efficiency and measurable outcomes [29], [33].

In addition, the result shows there was no statistically significant difference among employees in their response to the existing organizational culture or in their preference of desired future organizational culture based on the sex, age, and experience and employees work department. This strengthens the claim that culture is a shared values and belief system perceived commonly by employees of a given organization [14]. This has paramount importance in navigating cultural change desired or in diagnosing existing culture.

\section{CONCLUSION AND RECOMMENDATION}

\section{A. Conclusions}

Clan is the dominant cultural orientation at the moment in Ethiotelecom. Loyalty, sensitivity to customers and concern for people are central characteristics of the organization. In the future employees want their organization to be result oriented by adopting market culture. This type of culture mainly concerned in getting the job done. For this people need to be competitive and goal oriented. Studying organizational culture is crucial because it can provide guidance for managers in searching for ways to improve their organizations' effectiveness and performance. Identifying and knowing the culture type of the organization is important as the success of organization depends on the extent to which the culture matches the demands of the industry. Therefore, Ethiio-telecom Jimma branch offices need to move from clan oriented culture which characterized by loyalty and people focus to market culture which is result oriented to ensure competitiveness and larger market share sustainably.

\section{B. Recommendations}

Based on the result of the study it is implied that managers should navigate cultural change from the existing dominant culture -clan to the desired market culture to improve market share and competitiveness. The culture change should focus and involve the following important points. Culture can be diagnosed and changed at the relevant level of cultural analysis. This may be at the overall 
organization level, or it may be at the level of a subunit supervised by a manager.

Therefore, since statistically significant difference was not found among employees in terms of sex, age, experience and subunit of work department change efforts should be directed or involve all offices and every employee of the region offices. The leaders at the offices should define success in terms of measurable goal achievement and concern for getting the job done should be the primary focus of the offices. In addition, people need to be competitive and goal oriented and emphasis on winning should be the glue that holds the organization together rather than mere loyalty or tradition. Finally, reputation and market share should be common concerns for the organization.

\section{Implication and Future Direction}

Assessing an organization's culture may focus on the entire organization as the unit of analysis or one can assess different subunit cultures, identify the common dominant attributes of the subunit cultures, and aggregate them. This combination can provide an approximation of the overall organizational culture. Considering this understanding, the finding in the current study cannot portray the overall culture at Ethio-telecom company rather only represent the cultural profile of Jimma town offices. Therefore, the findings cannot be generalized to other offices across the country. To show overall picture of culture profile more similar study need be conducted in different places and pulled together.

\section{REFERENCES}

[1] Cameron, K. S. and Quinn, R. E. (2006). Diagnosing and Changing Organizational Culture: Based on the Competing Values Framework. San Francisco: The Jossey-Bass Business \& Management Series.

[2] Mihaela V. and Brătianu C. (2012). Organizational culture modeling, Management \& Marketing Challenges for the Knowledge Society, 7(2), pp. 257-276.

[3] Schein, E. H. (2004). Organizational Culture and Leadership ( $3^{\text {rd }}$ ed). USA: The Jossey-Bass business \& management series

[4] Cui, Y., Liu, Y. and Mou, J. (2018). Bibliometric analysis of organisational culture using CiteSpace. South African Journal of Economic and Management Sciences, 21(1), 2030 https://doi.org/10.4102/sajems.v21i1.2030.

[5] Sheridan, J. (1992). Organizational Culture and Employee Retention. The Academy of Management Journal, Vol. 35, No. 5 (Dec., 1992), pp. 1036-1056 https://doi.org/10.2307/256539.

[6] Alavi, M. and Leidner, D.E. (2006). An empirical examination of the influence of organizational culture on knowledge management practices. Journal of Management Information Systems, 22(3), pp.191-224.

[7] Fey, C.F. and Denison, D.R. (2003). Organizational culture and effectiveness: Can American theory be applied in Russia. Organization Science, 14(6), pp.686-706.

[8] Büschgens, T., Bausch, A. and Balkin, D.B. (2013). Organizational culture and innovation: A meta-analytic review. Journal of Product Innovation Management, 30(4), pp.763-781. https://doi.org/10.1111/jpim.12021.

[9] Hogan, S.J. and Coote, L.V. (2013). Organizational culture, innovation, and performance:A test of Schein's model. Journal of Business Research, 67(8), pp.1609-1621.

[10] Barney, J.B. (1986). Organizational culture: Can it be a source of sustained competitive advantage? Academy of Management Review, 11(11), pp. 656-665.

[11] Schein, E. H. (1992). The role of the CEO in the management of change. In T. A. Kochan, \& M. Useem (Eds.), Transforming Organizations (pp. 80 - 96). New York: Oxford University Press.

[12] Ravasi, D. and Schultz, M. (2006). Responding to organizational identity threats:Exploring the role of organizational culture. Academy of Management Journal,49(49), pp.433-458.
[13] Schein, E. H. (2010). Organizational Culture and Leadership (4 $4^{\text {th }}$ ed USA: The Jossey-Bass business \& management series.

[14] Cameron, K. S. and Quinn, R. E. (2011). Diagnosing and Changing Organizational Culture: Based on the Competing Values Framework. ( $3^{\text {rd }}$ ed.). San Francisco: The Jossey-Bass Business \& Management Series.

[15] Maximini, D. (2015). 'Organizational culture models, in the scrum culture: introducing agile methods in organization'. www.springer.com/978-3-319-11826-0.

[16] Belias, D., Koustelios, A., Vairaktarakis, G. and Sdrolias, L. (2015) Organizational Culture and Job Satisfaction of Greek Banking Institutions. Procedia - Social and Behavioral Sciences 175 ( 2015 ) 314 - 323. International Conference on Strategic Innovative Marketing, IC-SIM 2014, September 1-4, 2014, Madrid, Spain

[17] Helou, S. and Viitala, T. (2007).' How Culture and Motivation Interacts?- A Cross-Cultural Study'. Umeå universitet (MA thesis), http://www.diva-portal.org/smash/.

[18] Sinha, S., Singh, A., Gupta, N. \& Dutt, R. (2010) impact of work culture on motivation and performance level of employees in private sector companies. AOP 18(6), 49-67.

[19] Cheeran, M., Saji, K. and Joseph, G. (2015). Employee Motivation and Organizational Culture: A Study with Special Reference to Software Industry. International Journal of Innovative Research \& Development, 4(10), pp. 78-81.

[20] Parthasarathy, K. and Ramalingam, S. (2015). An empirical study on organization culture and its impact on employee motivation with reference to industrial estates in Chennai. I J A B E R, Vol. 13(1), pp.287-294.

[21] Sokro, E. (2012) Analysis of the relationship that exists between organizational culture, motivation and performance. Problems of management in the 21st century, 3, 106-119, [Online] ISSN 20296932.

[22] Yusof, H., MohameddSaid, N. \& Ali, S. (2016) A Study of Organizational Culture and Employee Motivation in Private Sector Company. Journal of Applied Environmental and Biological Sciences, 6(3S)50-54, ISSN: 2090-4274 www.textroad.com.

[23] Hartnell, C., Yi Ou, A. and Kinicki, A. (2011). Organizational Culture and Organizational Effectiveness: A Meta-Analytic Investigation of the Competing Values Framework's Theoretical Suppositions. Journal of Applied Psychology, vol. 96(4), pp.677-694.

[24] Kokt, D. and Merwe, C. (2009). Using the competing values framework (CVF) to investigate organisational culture in a major private security company. South African Journal of Economic and Management Sciences (SAJEMS), 12(3). PP. 343-352 DOI: 10.4102/sajems.v12i3.225.

[25] AlHarbi, S. and Abedelrahim, S. (2018). Organizational Culture Assessment using the Competing Values Framework (CVF) in Public Universities in Saudi Arabia: A Case Study of Tabuk University. International Journal of Business and Management, International Institute of Social and Economic Sciences, vol. 6(2), pp. 1-16.

[26] Silva, J., Couto e Melo, J., Chianca, T. and Dias, A. (2018). Relations between actual and desired culture on health Organizations: a competing values framework dimension's approach. RAHIS, Revista de Administração Hospitalar e Inovação em Saúde Vol. 15(1), pp. 127-142 DOI: http://dx.doi.org/10.21450/rahis.v15i1.4374.

[27] Santoriello, A.J. (2015). Assessing Unique Core Values with the Competing Values Framework: The CCVI Technique for Guiding Organizational Culture Change" Dissertations and Theses. Paper 2315 .

[28] Suderman, J. (2012) Using the Organizational Cultural Assessment (OCAI) as a Tool for New Team Development. Journal of Practical Consulting, 4 (1), 52-58. Regent University School of Business \& Leadership, Virginia Beach, USA. ISSN 1930-806X.

[29] Abbett, L., Coldham, A. and Whisnant, R. (2010). Organizational culture and the success of corporate sustainability initiatives: An empirical analysis using the Competing Values Framework University of Michigan (Un published MA thesis).

[30] Cameron, K. S., Quinn, R. E., DeGraff, J., \& Thakor, A. V. (2006). New horizons in management.Competing values leadership: Creating value in organizations. Edward Elgar Publishing. https://doi.org/10.4337/9781847201560.

[31] Creswell, J.W. (2012) Educational research: planning, conducting, and evaluating quantitative andqualitative research ( $4^{\text {th }}$ ed.). Boston: Pearson Eduction.

[32] Pallant, J. (2005). SPSS Survival Manual. A step by step guide to data analysis using SPSS for Windows (Version 12). Australia: Allen \& Unwin www.allenandunwin.com.

[33] Botti, A. and Vesci, M. (2018). Competing Value Framework and Public Administration: Managerial Insights, Theoretical Reflections 
and Practical Implications from Italy. International Business Research; 11(2), pp.147-160.

Abadir Abrahim Yusuf, a $\mathrm{PhD}$ candidate in the department of Management at Jimma University, Ethiopia. I received BA and MA in Language study from Addis Ababa University and MBA from Jimma University. More than 10 years of work experience as a Lecturer. Areas of research interest include quality management, performance measurement and organizational behaviors.

Shimels Zewdie Werke (PhD), Associate Professor, Management Department, Jimma University Jimma, Ethiopia.

1. $1^{\text {st }}$ Degree Business Management, Addis Ababa University, Addis Ababa, Ethiopia.

2. $2^{\text {nd }}$ Degree Master of Business Administration, Aligarh Muslim University, Aligarh, India.

3. $\mathrm{PhD}$ in Business Administration, Aligarh Muslim University, Aligarh, India.

About 33 years of experience in teaching and administration in university. 